\title{
15 \\ Multi-level Integrated Water Governance: Examples from New South Wales and Colorado
}

\author{
Andrew Ross
}

\section{Introduction}

Water governance refers to the range of political, social, economic and administrative systems that are in place to develop and manage water resources, and the delivery of water services, at different levels of society. The functions of water governance include the definition of sustainable limits and priorities for the use of water resources, the establishment of water-use entitlements and plans and organisations to administer them (Rogers and Hall 2003; Svendsen 2005). Decision-making in a watergovernance system takes place at many different spatial, temporal and jurisdictional scales (Cash et al. 2006; Young 2002). This decisionmaking involves trade-offs and compromises that are shaped by different social and political preferences and governance arrangements in different jurisdictions.

Historically, water governance has been centralised and characterised by top-down decision-making. Most water supply and demand problems were addressed by additional infrastructure development, with regulation employed, where necessary, to address point-source water pollution. Now water management is seen as including a much broader range of issues, 
including water for the environment, diffuse pollution from agriculture and climate change. Given the complexity of water management and related uncertainties, new approaches are required to guarantee sufficient water of satisfactory quality to meet competing demands. Integrated water supply and demand management and multi-level integrated water governance is needed using blends of regulation, market mechanisms and collaborative networks (Pahl-Wostl et al. 2005; Sabatier et al. 2005). Multi-level governance processes can be defined as systems of continuous negotiation at several territorial tiers, including vertical and horizontal coordination between governments, non-government actors, markets and civil society (Marks 1993).

The dispersion of water governance across multiple jurisdictions can lead to a number of benefits. It can capture variations in externalities arising from the use of water resources, ranging from transnational to local impacts. More decentralised jurisdictions can enable greater flexibility and better reflect heterogeneity of preferences among citizens (Hooghe and Marks 2001). Multiple jurisdictions facilitate innovation and experimentation (Gray 1973). Fragmentation or duplication of authority can, however, present problems in the management of large-scale water resources. Effective coordination across functions, scales and levels presents a key governance challenge (Cash et al. 2006).

Two models for coordination can be distinguished (Hooghe and Marks 2003). General purpose jurisdictions, such as state and local governments and their agencies (Type I), cover a wide range of issues and have a limited number of levels whose membership does not intersect. Special purpose jurisdictions, such as natural resource management organisations in New South Wales (NSW) and water districts in Colorado (Type II), cover a more limited number of issues, but the number of levels is not limited and memberships often intersect. The roles and interactions of these bodies are relatively dynamic. Research suggests that multi-level or polycentric governance (a mixture of Type I and Type II governance) is a more successful model for managing water resources than a hierarchical system (Ostrom 2005; Huitema et al. 2009), even though it can sometimes seem relatively chaotic (Blomquist and Schlager 2008). ${ }^{1}$

1 The concept of MLG originated in analyses of intergovernmental arrangements in the European Union (Bache and Flinders 2004). The concept of polycentric governance originated in American studies of city government service provision (Ostrom and Ostrom 1977). When MLG is defined to include both vertical and horizontal integration, and both public and private sector organisations as in this chapter - these concepts overlap substantially. 
Integrated water management involves the joint or coordinated use and management of surface water and groundwater in connected or unconnected resources. Integrated water management helps to enable optimal water use and to prevent adverse impacts of surface water and groundwater use on other water users, third parties and the environment (Blomquist et al. 2004; Ross and Martinez-Santos 2010).

Integrated water planning and management provides an interesting case study of multi-level governance (MLG) because it involves some special cross-boundary coordination challenges. Water catchments do not share the boundaries of social-political systems, and surface water and groundwater boundaries are different. The impacts of groundwater use are often much slower than surface water use, leading to intertemporal management issues. ${ }^{2}$

In the remainder of this chapter, MLG arrangements are explored in a comparative case study of integrated water management and planning in the Namoi region in NSW and South Platte basin in Colorado. These regions are selected for comparative study because they have similar biophysical and socio-economic conditions, including relatively dry climate, variable rainfall, water scarcity and a high proportion of water use in irrigated agriculture. The two regions also share a common spatial and jurisdictional scale: sub-basins under state government jurisdiction. These similarities assist a comparison of the impact of different policy settings and MLG approaches on integrated water use and management.

In both the Namoi and South Platte regions, the main integrated water management problem in recent decades has been how to maintain the benefits of groundwater pumping without adverse impacts on surface water supplies, environmental assets or long-term groundwater resources. This problem has been approached in different ways in the two regions, reflecting their different multi-level water governance arrangements.

2 The interactions between some alluvial surface water and (shallow) groundwater resources can be relatively fast - within months - but in most cases the impacts of groundwater pumping on connected surface water and water-dependent ecosystems can take many years, or hundreds of years in some cases. 


\section{Integrated water governance in New South Wales and Colorado}

Both NSW and Colorado are experiencing increasing water scarcities owing to drier climatic conditions, increasing human populations and increasing consumptive demands for water (Blomquist et al. 2004; Pigram 2006). Some surface water and groundwater resources are being depleted or degraded, and there are increasing concerns about the impacts on riverine environments, wetlands and floodplains. Integrated surface water and groundwater management presents many opportunities to mitigate these problems and to insure against water scarcity. Integrated water management has been actively pursued in Colorado and other states in the western United States, but not in NSW (or most jurisdictions in the Murray-Darling Basin, MDB). What explains this phenomenon, and how has MLG affected the outcome?

\section{Core water governance approaches}

Ostrom (2005) distinguishes between constitutional, collective choice and operational rules and rule-making. Constitutional decisions involve the establishment of water decision-making bodies and their membership, collective choice includes making water policies or broad allocations of water resources, and operational rules involve more frequent decisions about the implementation of policies and plans. The choices of water users, policymakers and managers in specific water management areas are shaped and constrained by 'core' principles of water governance and by previous decisions about institutions (laws, rules and management organisations) and instruments. The prior-appropriation system in Colorado requires integrated water management in tributary water resources. Separate surface water and groundwater planning and allocation in NSW does nothing to encourage integrated water management.

In Australia's federal system, water governance takes place at a number of levels at the jurisdictional and river basin scale. Essentially, it is a relatively centralised and hierarchical governance system. The Council of Australian Governments (COAG) (Commonwealth, state and territory) has led responsibility for national water policy. In 2004, COAG established an intergovernmental agreement on a national water initiative 
(NWI) (COAG 2004). The NWI provides for comprehensive planning and secure, tradeable water-access entitlements for both surface water and groundwater.

The $1992 \mathrm{MDB}$ agreement covers surface water allocation between MDB jurisdictions. The agreement includes a 'cap' on surface water use in the MDB, but does not include any limit on groundwater use. In the MDB, water plans are the main instrument used for allocating water. Markets are also used, especially for reallocating surface water. Groundwater trade is less well developed than surface water trade. ${ }^{3}$ Water-use limits and allocations for each water resource are established by state water plans. Tradeable water-use entitlements are allocated according to the histories of use, usually over periods in the relatively recent past.

The NSW Water Management Act 2000 gives effect to the COAG 1994 reforms ${ }^{4}$ and the NWI by establishing a framework of water management based on clearly defined tradeable water-access entitlements/licences. The Water Management Act authorises the preparation of surface water- and groundwater-sharing plans to allocate water resources. ${ }^{5}$ The rules for allocation of water are set out in water-sharing plans for specified watermanagement areas (Montoya 2010). Surface water and groundwater plans have generally been made separately. The Australian Government's Water Act $2007^{6}$ requires the preparation of a new, integrated surface water and groundwater plan for the MDB and its catchments.

In the US federal system of governance, each state has 'plenary control' over the waters within its boundaries, and is free to develop whatever system of water-rights administration it chooses (Hobbs 1997). In the western United States, state law underpins the doctrine of prior appropriation, which provides the basic system for the allocation of water resources (Kenney 2005). Under this doctrine, the earliest user of a water source has the right to apply it to a beneficial use and to exclude others. If low stream flows prevent 'senior' rights from diverting the water to which they are entitled, the 'seniors' put a 'call' on the river, requiring all

3 Groundwater trade and groundwater-surface water trade is constrained by uncertainties about the long-term impacts of moving groundwater use from one location to another.

4 www.austlii.edu.au/au/legis/nsw/consol_act/wma2000166/ [Accessed: 16/02/2011]. Amendments to the Act enable implementation of the National Water Initiative in NSW.

5 A number of water-sharing plans are now in place covering various water resources in the Namoi region. www.water.nsw.gov.au/Water-management/Water-sharing-plans/Plans-commenced/ plans_commenced/default.aspx [Accessed: 16/02/2011].

6 www.comlaw.gov.au/Series/C2007A00137 [Accessed: 24/12/2014]. 
upstream rights 'junior' to the caller to stop diverting water until adequate streamflow is restored (Howe 2008). In addition, many water resources in the United States overlap state boundaries. These resources are regulated by interstate compacts.

In Colorado, the management and use of surface water and groundwater is closely integrated. In practice, the primary purpose of integrated surface water and groundwater management is to maintain stream flows to protect senior surface water rights holders. This also enables Colorado to comply with interstate river compacts, including the South Platte compact between Colorado and Nebraska. There are four types of groundwater rights. ${ }^{7}$ In this comparative case study the emphasis is on tributary groundwater, which is hydrologically connected to a surface water stream. Tributary groundwater is subject to the prior-appropriation system (MacDonnell 1998), and surface water and groundwater are managed as a single connected resource. Tributary groundwater wells can be 'shut down' unless they can ensure that senior surface water rights are maintained.

\section{The development of integrated water use and governance}

Water users in both regions have a long history of integrated use and management of surface water and groundwater.

In NSW and Colorado, both surface water and groundwater provide an important source of regional water supplies. The primary source fluctuates according to climatic variation. Integrated water use has led to more flexible use of water and helped adaptation to variable water supplies.

Water users in both regions choose between diverse water supplies on the basis of water availability, cost and quality. Interviews with user associations in both regions indicate that, when water users have a choice, they usually prefer surface water, because the cost of delivered surface water is usually

7 Tributary, non-tributary, not non-tributary and designated groundwater. Non-tributary groundwater is almost totally disconnected from surface water. Not non-tributary groundwater is connected but only over a long period of time. The definition for non-tributary groundwater is rigorous. A proposed diversion cannot deplete surface streams of more than 0.1 per cent of the proposed diversion volume in any single year for up to 100 years. www.douglas.co.us/water/coloradostate-water-law/ [Accessed: 09/04/2015]. 
less than groundwater that they have to extract themselves. ${ }^{8}$ Some users depend on groundwater because delivered surface water is unavailable. Many users turn to groundwater during dry periods when less surface water is available.

Surface water and groundwater management has gone through similar phases in the two states (Pigram 2006; Heikkila 2000). Initially, surface water and groundwater use was not restricted. Then, as surface water demand exceeded availability, groundwater use increased. Eventually, this led both users and authorities to be concerned about the impact of groundwater pumping on surface water flows and aquifers. Finally, groundwater pumping was restricted and/or groundwater users were required to make good their impacts on surface water users.

The two jurisdictions have taken different approaches to multi-level water governance arrangements, as shown in Table 15.1.

Table 15.1: Water entitlements and management instruments in New South Wales and Colorado

\begin{tabular}{|c|c|c|}
\hline & New South Wales & Colorado \\
\hline Water rights & $\begin{array}{l}\text { Distribution of water rights } \\
\text { determined by political choice; } \\
\text { rights have different 'security', } \\
\text { depending on priority }\end{array}$ & $\begin{array}{l}\text { Distribution of water rights determined } \\
\text { by prior appropriation: 'First in time, } \\
\text { first in right' (point of diversion, place } \\
\text { and time of use, purpose, amount) }\end{array}$ \\
\hline Instruments & $\begin{array}{l}\text { Access and allocation rules in } \\
\text { state water plans; reallocation } \\
\text { of water rights through water } \\
\text { markets }\end{array}$ & $\begin{array}{l}\text { 'Calls' by senior water rights holders; } \\
\text { decrees by courts; junior water } \\
\text { entitlement holders have to buy senior } \\
\text { rights, mitigate impacts or cease } \\
\text { to pump }\end{array}$ \\
\hline
\end{tabular}

These differences are illustrated by experience in the Namoi region in NSW and the South Platte region in Colorado.

\section{New South Wales}

Integrated water management in NSW has been biased towards surface water supplies and storage. In the 'development' stage of water resource management, various NSW state governments built surface water storages and delivery infrastructure to supply irrigation areas (Wilkinson 1997).

8 These interviews were carried out by the author during research for his $\mathrm{PhD}$, which examined integrated surface water and groundwater use in the Murray-Darling Basin and western United States. Water-quality issues, such as sedimentation or salt content, also affect water supply preferences. 
The NSW Government issued a substantially greater volume of surface water and groundwater entitlements than long-term average availability of the two resources. In the Namoi region, surface water entitlements are supplied from releases from Split Rock and Keepit dams. The majority of the remaining surface water resource flows are provided for environmental flows (Barma Water Resources et al. 2012), although farmers are allowed to opportunistically harvest water during high-flow events.

During major periods of dry weather, groundwater use in the Namoi increased substantially, leading to adverse impacts such as falling groundwater levels, declining stream flows and increasing pumping costs. Water users and managers understood that surface water and groundwater resources were connected. Surface water and groundwater monitoring networks were put in place and substantial research programs were undertaken (Kelly et al. 2007). However, surface water and groundwater plans have generally been prepared separately. In NSW, surface water plans do not generally consider connections with, or impacts on, groundwater. ${ }^{9}$ Groundwater plans usually do consider connections with, and impacts on, surface water, but the analysis is limited (NWC 2009).

Restrictions on surface water and groundwater use were introduced incrementally and separately, with the aim of minimising impacts on water-dependent farming industries and communities. Groundwater restrictions were only developed when groundwater use substantially exceeded sustainable limits, or when groundwater pumping threatened surface water availability. The introduction of restrictions involved periodic negotiations between governments and water-user representatives. The NSW Government placed embargoes on new surface water and groundwater licences in 1976 and 1984 respectively. Volumetric limits were introduced for surface water licences in 1984 to restrict the growth of water use (Wilkinson 1997). In the early 1980s, NSW authorities allowed 'controlled depletion' of groundwater resources, anticipating that wet years would recharge them. An embargo on stressed groundwater systems was imposed in 1985 (Williams 1998). In 1994-95, groundwater

9 There are some examples of integrated water planning in South Australia, the Australian Capital Territory (where there is one integrated surface and groundwater plan for the territory) and a few areas in Queensland. The complicated Peel Valley water-sharing plan in the Namoi region includes different sets of rules to manage eight different water resources, with varying degrees of connectivity. 
use rose to substantially above annual recharge levels. This prompted further embargoes on new groundwater allocations in the Upper Namoi (NGERP 1999).

\section{Colorado}

The key policy problem facing Colorado authorities is how to make beneficial use of both surface water and groundwater resources, while upholding the legal rights of senior water users.

In Colorado, prior appropriation has encouraged the integration of surface water and groundwater management. Surface water users hold the most senior rights and, as groundwater use expanded after World War II, senior surface water users became increasingly concerned about the impact of groundwater pumping on surface water supplies. 'Calls' by senior surface water-rights holders on groundwater pumpers prompted initiatives by users and state authorities, and legal and policy innovations to enable groundwater use to continue.

The Water Rights Determination and Administration Act 1969 in Colorado required tributary groundwater rights to be adjudicated and included in the prior-appropriation system. From that time, management of tributary surface water and groundwater has been integrated. In order to allow continued use and development of groundwater without jeopardising senior surface water rights, groundwater users have been required to bring forward long-term or temporary plans to supply water to mitigate the impact of pumping on senior surface water-rights holders ${ }^{10}$ (Blomquist et al. 2004).

In the South Platte region, shallow alluvial groundwater resources are closely connected with rivers, and their use has an almost immediate impact on surface water stream flow. These effects are noticeable to senior surface water-rights holders within a single irrigation season. The relatively early adjudication of groundwater by 1972 has provided a strong driver towards integrated water management. This led to the development of augmentation plans negotiated between water users and approved by the water courts. In March 1974, water appropriators in the South Platte basin agreed on a set of rules for regulating wells. These rules defined

10 There are some differences in the terminology and detail relating to these plans in the Arkansas and South Platte basins. 
a timetable for phasing out well pumping, but allowed wells covered by an approved augmentation plan to continue to pump during the summer, provided that they did not injure downstream senior appropriators. The augmentation plans also have to take account of the provisions of the South Platte River compact. These limit diversions from the river between 1 April and 15 October in order to guarantee streamflow to downstream states, including Nebraska.

\section{Multi-level water governance processes, levels and actors}

Integrated water management requires effective multi-level coordination and broad stakeholder participation. The successful implementation of integrated water management depends on striking an effective balance between broad direction and coordination and local initiative (Ross and Dovers 2008; Turral and Fullagar 2007).

Table 15.2 summarises water governance in NSW and Colorado. Water governance in NSW is relatively hierarchical and centralised, with government agencies controlling water planning and allocation, whereas water governance in Colorado is multi-centred or polycentric, with functions shared between water courts, water users, water districts and government agencies.

Table 15.2: Water governance in New South Wales and Colorado

\begin{tabular}{|l|l|l|}
\hline & New South Wales & Colorado \\
\hline Management 'style' & Hierarchical & Polycentric \\
\hline Management & $\begin{array}{l}\text { State government and } \\
\text { agencies control water } \\
\text { planning and allocation, } \\
\text { catchment management } \\
\text { agencies and water- } \\
\text { user groups play a role in } \\
\text { implementation }\end{array}$ & $\begin{array}{l}\text { Water courts arbitrate prior } \\
\text { appropriation, water users } \\
\text { initiate priority calls and } \\
\text { mitigation activities, water } \\
\text { districts and government } \\
\text { agencies play an important } \\
\text { role in implementation }\end{array}$ \\
\hline
\end{tabular}

\section{New South Wales}

The main factors that influence MLG processes in NSW are water resources and their availability, national and state policies and state water plans. The most influential stakeholders are the NSW minister responsible 
for water and state officials. The water-planning process is the primary arena for negotiation, where water allocation is determined and water-use conflicts are resolved.

The NSW Government has primary responsibility for managing water in the state. The NSW Minister for Primary Industries has the primary responsibility for the management of NSW water resources. ${ }^{11}$ The minister's functions and duties include implementing national agreements and policies, developing and implementing water-sharing policies and plans, administering and enforcing access licences and water-use approvals and distributing water. Water-sharing plans set out water allocations between different uses/users and operational rules for water management. ${ }^{12}$ Watersharing plans have effect for 10 years and are reviewed after five years. ${ }^{13}$ The development of water-sharing policies and plans involves ongoing negotiation between governments, water users and third parties.

The Office of Water in the Department of Primary Industries ${ }^{14}$ carries out many of the minister's functions, including the development of water policy and plans and the administration, monitoring and enforcement of access licences and water-use approvals. Surface water and groundwater policy and planning functions are joined at the highest level of decisionmaking. Otherwise, they are separate but coordinated. Technical and implementation functions are often carried out separately. Regional staff at Tamworth and Narrabri are responsible for analysis, liaison, monitoring, metering, inspection and compliance.

Water management committees (WMCs) and community advisory committees (CACs) are established by the minister to prepare and/or provide advice about water sharing. These committees include between 12 and 20 members appointed by the minister. They include representatives of environment protection groups, water users (including irrigators), local councils, traditional owners, catchment management boards, the Office of Water and a nominee of the minister. CACs are similarly constituted to WMCs but have a purely advisory role.

11 The Minister for Primary Industries took over these responsibilities following a change of government in March 2011.

12 These rules include shares of surface water to be made available to water-entitlement holders, and cease-to-pump rules for rivers and streams subject to too low or intermittent flow.

13 www.austlii.edu.au/au/legis/nsw/consol_act/wma2000166/s43.html [Accessed: 24/12/2014].

14 www.water.nsw.gov.au [Accessed: 24/12/2014]. 
In practice, consultation often appears more symbolic than real because it takes place after policy changes have been made and/or does not take sufficient account of stakeholder views (Bowmer 2003). Also, the minister may overrule the consultative document and make a separate plan. This can provoke conflicts and legal action, as in the case of the upper and lower Namoi groundwater plan (Gardner et al. 2009). So far, the NSW Court of Appeal has upheld the statutory application of minister's plans and there is no case of a plan being stopped by court action.

Catchment management organisations are special purpose bodies established under the Catchment Management Act 1989 or the Catchment Management Regulation 1999. They are established to promote healthy and productive catchments by identifying objectives, strategies and actions to manage natural resources. Catchment management organisations represent an interesting innovation to integrate policy at the regional scale. They have responsibilities for land and environmental conservation and water quality, but not for water allocation, and their effectiveness is constrained by limited personnel and budgets (Ross 2008; Robins and Dovers 2007).

A number of special purpose bodies manage water infrastructure and delivery. State Water owns, maintains, manages and operates major infrastructure to deliver bulk water. ${ }^{15}$ Irrigation corporations are privately owned organisations that own and operate water supply infrastructure in specific irrigation areas. Private irrigation districts are legal entities constituted by landholders for the construction, maintenance and operation of water supply and drainage infrastructure. Namoi Water is the peak industry group for irrigated agriculture, and covers 60-70 per cent of all water users (Productivity Commission 2003).

\section{Colorado}

The main factors that influence multi-level water governance processes in Colorado are water resources and their availability and the priorappropriation system of water allocation. The most influential stakeholders are the water courts, special purpose water districts and the state and regional engineers. ${ }^{16}$ In Colorado, water courts are the primary arena for determining water allocation and resolving conflicts.

15 State Water supplies approximately 6,300 licensed water users on the state's regulated rivers along with associated environmental flows: www.water.nsw.gov.au/water-licensing [Accessed: 11/12/2010]. 16 The state engineer is the head of the Colorado Department of Water Resources. 
The courts define (adjudicate) and enforce appropriation of rights, including the amount, priority, location and beneficial use of water rights, the approval of exchanges and plans for augmentation. The earliest water-rights decrees in Colorado were adjudicated by the district court system - there are 80 water districts in Colorado. Most administration is still done at the level of water districts. A water commissioner serves each water district. The Water Rights Determination and Administration Act 1969 authorised the establishment of seven water courts and water divisions, based on the seven major river-drainage basins in Colorado. The judge in each water court is designated by the Supreme Court to review water-right applications within the relevant water division. The judge may appoint a water referee to gather evidence and consider applications (Vranesh 1987).

Well owners that pump from alluvial aquifers are required by law to belong to an augmentation plan, such as the Groundwater Appropriators of South Platte, the Central Colorado Water Conservancy District, or an individual augmentation plan. Groundwater users, working with state authorities, develop decreed or temporary augmentation plans to offset their impacts on senior users. The development of these plans involves ongoing negotiation. Formal legally decreed plans take several years to develop and to be agreed among water users. Most groundwater appropriations are covered by temporary plans reviewed, revised if necessary, and approved by the state engineer on an annual basis. Groundwater users collaborate to obtain surface water when it is plentiful, for example during the snowmelt season. They use various techniques to return water to the river, including infiltration from irrigation ditches and ponds, delivery from special purpose surface water storages or simply not using their purchased entitlement (Blomquist et al. 2004)

The state and division engineers provide information and technical resources to appropriators, the courts and the state legislature allowing them to implement the water-rights system. Appropriators, the state engineer, the engineer's seven divisional offices and water commissioners employed by the state engineer participate in monitoring and enforcing water rights (Knox 2008). In Colorado, while the water courts have primary responsibility for administering water rights and determining claims, the Division of Water Resources has played a key role in developing the science that underpins integrated water management plans, and monitoring and enforcement. 
The Colorado Water Conservation Board ${ }^{17}$ is appointed by the governor. It formulates policy for water development programs, provides funds for water projects, acquires and manages in-stream flow rights and assists in interstate compact administration.

Many federal departments and agencies play a role in state water management. Key departments include the US Fish and Wildlife Service, which administers the Endangered Species Act 1973 and fisheries management; the US Environmental Protection Agency, which administers national water standards; and the US Army Corps of Engineers, which develops and operates water infrastructure. The federal government also has a strong presence in water issues in relation to American Indian and international treaty obligations, and public land management. Federal and state laws and programs don't always fit together easily. Federal laws and programs that encourage leaving water in streams can conflict with state water laws and programs that encourage maximum diversion and consumptive use (Kenney et al. 2001).

Under the Water Conservancy Act 1937, Colorado's legislature authorised the creation of special purpose water-conservancy districts at the subbasin scale. Fifty of these public entities, some divided into sub-districts, engage in a wide range of water issues, including development and management of water projects, water conservation, distribution, waterquality protection, flood control, legislation and education. The district's taxing ability allows them to borrow money for projects and repay it with tax revenue. Water conservancy districts may acquire and develop water rights, development augmentation plans and/or deliver water directly. These districts play a key role in integrated water management, regional coordination and innovation. Private associations were created across Colorado in the 1800 s to develop, maintain and deliver irrigation water. There are over 700 metropolitan districts and more than 100 water and sanitation districts in Colorado. These entities commonly raise money for infrastructure (Jones and Cech 2009).

A 27-member Interbasin Compact Committee has been established by the legislature ${ }^{18}$ and separate basin round tables also were established by the Act to coordinate discussions on water issues and encourage locally driven collaborative solutions.

17 cwcb.state.co.us/Pages/CWCBHome.aspx [Accessed: 25/05/2011].

18 Colorado Water for the 21st Century Act. 


\section{Recent developments in integrated water planning and governance}

Recent developments in integrated water governance in NSW and Colorado serve to illustrate some of the pros and cons of the two systems - centralised planning and allocation in NSW and prior appropriation in Colorado. Neither system has made the best use of integrated surface water and groundwater management to adjust to water-supply variability and scarcity.

\section{New South Wales: Namoi region}

Following the Water Management Act 2000, separate surface water- and groundwater-sharing plans were prepared in the Namoi region. The surface water-sharing plan for the upper and lower Namoi regulated rivers ${ }^{19}$ established water allocations based on historical average diversion limits. Annual water allocations to municipal and irrigation users vary according to the amount of water available in the major water storages. Irrigators also have access to supplementary water allocations following high rainfall events and on-farm water harvesting allowances. These arrangements have encouraged large, on-farm surface water storages and discouraged aquifer storage and recovery (Ross 2012).

The groundwater management plan was more controversial and contested. In 1994-95, drought-driven groundwater use in the upper and lower Namoi groundwater management area increased to about double the long-term average aquifer recharge. After a protracted negotiation, taking into account economic impacts of reduced groundwater use (Wolfenden \& Van der Lee 2002), stakeholders were unable to agree on a watersharing plan. In 2003, the NSW Minister for Water issued a draft plan that included water-allocation reductions of 51 per cent in the Lower Namoi and 61 per cent in the Upper Namoi.

Water licence holders were strongly critical of the process for developing the Namoi groundwater-sharing plan. The main argument was about whether entitlement reductions should be equalised 'across the board', as proposed

19 The water-sharing plan for the Upper Namoi and Lower Namoi Regulated River Water Sources was gazetted in 2003 (DIPNR 2004). The flows in regulated water sources are controlled by dams and weirs. 
in the minister's plan, or adjusted in favour of irrigators who had developed their enterprise and were regularly using a large proportion of their entitlement (active users). ${ }^{20}$ The plan was not finalised and implemented until governments and groundwater users negotiated a formula for water reductions that took account of historical use (Department of Natural Resources 2006). While the minister's intervention was necessary to break the negotiation deadlock, active participation of water users was needed to come up with an acceptable formula for reducing groundwater entitlements. Acceptance of the plan was also conditional on financial assistance to help irrigators to make a phased transition to sustainable extraction levels over 10 years.

\section{Colorado: South Platte region}

Augmentation plans and temporary (non-decreed) substitute supply plans ${ }^{21}$ by groundwater users became the main mechanism for integrated water management in Colorado. From 1972 to 2001, the courts allowed the state engineer to play an independent role in facilitating and approving temporary water-supply plans. These plans allowed groundwater users to continue to pump even without completion of the formal legal procedures required to establish an augmentation plan. The temporary plans were coordinated by a group of well owners, the Groundwater Appropriators of the South Platte. In recent years, the authority of the engineer to approve temporary plans has been challenged, and the balance of influence has swung back towards the courts and the legislature.

Temporary supply plans violated the prior-appropriation doctrine because they did not fully replace 'out of priority' stream depletions. In 2001, the Colorado Supreme Court ruled (Empire Lodge Homeowners Association $v$ Moyer) that the legislature did not give the state engineer authority to approve temporary water-supply plans. The state engineer filed proposed new rules in May 2002, but more than 30 water-user entities

20 Water-entitlement holders who had invested heavily and were using a large proportion of their entitlement considered that they should get a larger allocation than entitlements holders who were not using their allocations. This formula did not, however, give any preference to entitlements holders who had reduced water use by investing in water-saving technology. Also, many farmers had large investments that depended on regular small supplies of water.

21 These plans include a list of members and wells, estimates of the amount of water to be pumped in the coming and previous irrigation season, and an amount of water to replace a priority depletion and offset injuries to senior rights (MacDonnell 1998). 
and individuals opposed the revised rules and the Water Court and the Supreme Court ruled that the state engineer lacked authority to approve replacement plans (Simpsonv Bijou Irrigation).

In 2003, the governor of Colorado signed a bill allowing annual approvals of substitute water-supply plans for three more years. However, negotiation of these plans for 2002-04 was complicated by the severe drought. In 2004, well-owner associations could not obtain replenishment water and the divisional engineer ordered 450 groundwater wells to cease pumping. This was a perverse outcome at a time of severe water shortage and also had the effect of drying up 30,000 acres of cropland, with immediate, severe impacts on the farms and associated rural communities (Howe 2008). The future for many groundwater pumpers remains unclear.

\section{Key lessons from the case studies}

The two case studies illustrate the strengths and weaknesses of Type I and Type II governance systems. Predominantly Type I systems, such as water governance in NSW, resolve coordination problems and conflicts by centralisation of decision-making. This enables a comprehensive and relatively low-cost approach taking account of both socio-economic and environmental issues. It also allows governments flexibility in their approach to resolving (or deflecting) conflicts. The risk of this approach is lack of broad community engagement and support. This can lead to protracted opposition and conflict, as in the case of the Namoi groundwater plan. Type I governance also tends to separate innovation by water users and governments, thus reducing the potential for publicprivate partnerships.

Systems with strong Type II elements, such as water governance in Colorado, resolve coordination problems and conflicts by disaggregating water governance and encouraging the creation of special purpose organisations to deal with particular coordination problems and conflicts. This approach encourages community ownership and participation and manages costs by limiting the scope of problems to be solved. In Colorado, it has encouraged a good deal of technical innovation by groundwater users, which has, in turn, prompted managerial innovation by government agencies. The risk of this approach is a lack of commonality and consistency. The groundwater augmentation plans in Colorado do not take account of environmental water needs or remote impacts, and 
the informal groundwater pumping agreements are under pressure owing to increasing municipal demand and climate change, as shown in the developments after the 2002-04 drought.

A report prepared for the Western States Water Council concludes that states should not overtake local planning but should establish policies that facilitate the flow of information from water-resource agencies to local planning agencies. This requires local governments to create and adopt comprehensive plans that include water-resource elements. The states should offer technical and financial support for watershed organisations and should work with stakeholders to find innovative ways of allowing transfers of water from agriculture to urban uses while avoiding or mitigating damage to agricultural economies or environmental values (Bell and Taylor 2008).

The two case studies also illustrate some strengths and weaknesses of court- and government-led governance systems. The government-led bureaucratic system in NSW can respond more quickly and more flexibly when water-use conflicts occur. The minister's power to make a minister's plan allows the government to resolve water-sharing conflicts when users cannot agree among themselves. The risk of this system is a lack of transparency or community engagement, as illustrated by the 2003 Namoi groundwater plan. There is also a risk that a water governance system and plans developed over a long period of time at substantial cost may be undermined or abandoned because of short-term political considerations.

In Colorado, the prior-appropriation system creates certainty for users once adjudication of rights has taken place. Court processes require the issues involved in water-use conflicts to be tabled and dealt with by means of clearly defined processes. Intermediaries (water referees, water commissioners) play an important role in developing agreements. The disadvantage of the system is that it can be relatively costly for participants and that parties without adjudicated rights are excluded from negotiations. Informal agreements reduce costs but may not be robust during water scarcities. In addition, the system can be inflexible in the case of severe water shortages, when senior water rights holders insist on their rights regardless of the social and political costs, as occurred in Colorado after the 2002-04 drought.

Integrated water management requires a blend of jurisdiction-wide and local approaches. This could include: 
- a jurisdictional-scale approach to sustainable-use limits, projections of surface water and groundwater availability and demand, and integrated water management strategies

- locally developed integrated surface water and groundwater use, storage and transfer rules, and management organisation.

This multi-level approach can avoid the difficulties involved in drafting and communicating a fully detailed management plan at the river basin or jurisdictional scale, but at the same time ensure a coordinated approach to water management at those scales.

Further research is needed on how to improve links and collaboration between higher level and local processes, over long-term water-planning periods. Research on long-term collaborative processes and institutions for integrated water management is particularly important because of the disjuncture between relatively short-term political cycles and the longterm effects of groundwater use on the other users and the environment.

Finally, the case studies illustrate that there is no magic formula for a robust system of water governance. Effective water governance is likely to include a well-developed legal and policy framework, well-defined and flexible water rights and a range of Type I and II water governance organisations with strong coordination arrangements. But the best water governance arrangements may not be robust in the face of severe, unexpected water scarcities. It is difficult to resolve water-sharing conflicts when the parties cannot find common ground. It is especially difficult to reduce water use when people depend on it.

\section{References}

Bache, I. \& Flinders, M. (eds) (2004). Multi-level Governance. Oxford University Press. doi.org/10.1093/0199259259.001.0001

Barma Water Resources, Thurtell, L. \& Wettin, P. (2012). Environmental Water Delivery: Namoi River. Prepared for Commonwealth Environmental Water, Department of Sustainability, Environment, Water, Population and Communities, Canberra.

Bell, C. \& Taylor. J. (2008). Water Laws and Policies for a Sustainable Future: A Western States Perspective. Western States Water Council, Murray, Utah. 
Blomquist, W. \& Schlager, E. (2008). Embracing Watershed Politics. University of Colorado Press, Boulder.

Blomquist, W., Schlager, E. \& Heikkila, T. (2004). Common Waters Diverging Streams. Resources for the Future, Washington.

Bowmer, K. (2003). Reflections on Developing a Water Sharing Plan. In: Wilson, B.P. \& Curtis, A. (eds) Agriculture for the Australian Environment. Proceedings of the 2002 Fenner Conference, Charles Sturt University, Albury.

Cash, D., Adger, W., Berkes, F., Garden, P., Lebel, L., Olsson, P., Pritchard, L. \& Young, O. (2006). Scale and Cross-Scale Dynamics: Governance and information in a multilevel world. Ecology and Society, 11(2): 8. doi.org/10.5751/ES-01759-110208

COAG (2004). Intergovernmental Agreement on a National Water Initiative between the Commonwealth of Australia and the Governments of New South Wales, Victoria, Queensland, South Australia, the Australian Capital Territory and the Northern Territory. Council of Australian Governments, Canberra.

Department of Natural Resources (2006). Key Amendments to the Water Sharing Plan for the Upper and Lower Namoi Groundwater Sources 2003. Sydney.

DIPNR (2004). A Guide to the Water Sharing Plan for the Upper Namoi and Lower Namoi Regulated Water Sources. Department of Infrastructure, Planning and Natural Resources, Sydney.

Gardner, A., Bartlett, R.H., Gray, J. \& Carney, G. (2009). Water Resources Law. LexisNexis Butterworths, Chatswood, New South Wales.

Gray, V. (1973). Confusion in the States: A diffusion study. American Political Science Review, 67: 1174-85. doi.org/10.2307/1956539

Heikkila, T. (2000). Linked Policy Changes and Resource Management Decisions: A Game Theoretic Analysis of Coordinated Water Management in Colorado. Research Supported by National Science Foundation and US Environmental Protection Agency, Grant Number R824781. School of Public Administration and Policy, University of Arizona, Tucson. 
Hobbs, G. (1997). Colorado Water Law: An historical overview. University of Denver Water Law Review, 1(1): 1-72.

Hooghe, L. \& Marks, G. (2001). European Integration Online Papers. $5(11)$.

level Governance. American Political Science Review, 97(2): 233-43.

Howe, C. (2008). Water Law and Economics: An assessment of river calls and the South Platte Well shut down. University of Denver Water Law Review, 12: 181-96.

Huitema, D., Mostert, E., Egas, W., Moellenkamp, S., Pahl-Wostl, C. \& Yalcin, R. (2009). Adaptive Water Governance: Assessing the institutional prescriptions of adaptive (co-)management from the government's perspective and defining the research agenda. Ecology and Society, 14(1): 26. doi.org/10.5751/es-02827-140126

Jones, P.A. \& Cech, T. (2009). Colorado Water Law for Non-Lawyers. University Press of Colorado, Boulder.

Kelly, B., Merrick, N.P., Dent, B., Milne-Home, W. \& Yates, D. (2007). A Scoping Study on Groundwater Knowledge and Gaps in the Namoi Catchment Management Area. National Center for Groundwater Management Report, NCGM 2007/1. Cotton Catchment Communities CRC, University of Technology, Sydney.

Kenney, D. (ed.) (2005). In Search of Sustainable Water Management: International Lessons for the American West and Beyond. Edward Elgar, Cheltenham.

Kenney, D., Nichols, P. \& Murphy, M. (2001). Water and Growth in Colorado: A Review of the Legal and Policy Issues. Water Resources Centre, University of Colorado School of Law, Boulder.

Knox, K. (2008). Water Administration in Colorado: The daily practice and legal authority. CBA-CLE, Denver, Colorado.

MacDonnell, L. (1998). Integrating Tributary Groundwater Development into the Prior Appropriation System: The South Platte Experience. Completion Report No 148. Colorado Water Resources Research Institute, Denver. 
Marks, G. (1993). Structural Policy and Multi-level Governance in the EC. In: Cafruny, A. \& Rosenthal, G. (eds) State of European Community. Vol. 2. Lynne Rienner, Boulder, Colorado, and Longman, London, pp. 391-410.

Montoya, D. (2010). Water: Regulatory Frameworks in Rural NSW. NSW Parliamentary Research Service, Sydney.

NGERP (1999). Report of the Namoi Groundwater Expert Reference Panel on the Ground Water Allocation Adjustment Process in the Namoi Valley, NSW. Namoi Groundwater Expert Reference Panel, Sydney.

NWC (2009). Australian Water Reform 2009: Second Biennial Assessment of Progress in Implemention of the National Water Initiative. National Water Commission, Canberra.

Ostrom, E. (2005). Understanding Institutional Diversity. Princeton University Press.

Ostrom, V. \& Ostrom, E. (1977). A Theory for Institutional Analysis of Common Pool Problems. In: Hardin, G. \& Baden, J. (eds) Managing the Commons. Indiana University Press, Indiana, pp. 157-72.

Pahl-Wostl, C., Downing, T., Kabat, P., Magnuszewski, P., Meigh, J., Schlueter, M., Sendzimir, J. \& Werners S. (2005). Transition to Adaptive Water Management; the NeWater Project. NeWater Report, 1. University of Osnabrück, Germany.

Pigram, J. (2006). Australia's Water Resources: from Use to Management. CSIRO, Collingwood, Australia.

Productivity Commission (2003). Water Rights Arrangements in Australia and Overseas. Commonwealth of Australia, Canberra.

Robins, L. \& Dovers, S. (2007). NRM Regions in Australia: The 'haves' and 'have nots'. Geographical Research, 45(3): 273-90. doi. org/10.1111/j.1745-5871.2007.00460.x

Rogers, P. \& Hall, A. (2003). Effective Water Governance. TEC Background Papers No. 7. Global Water Partnership Technical Committee, Sweden. 
Ross, A. (2008). Australia. In: Jordan, A. \& Lenschow, A. (eds) Innovation in Environment Policy: Integrating the Environment for Sustainability, Edward Elgar, Cheltenham, pp. 289-310. doi.org/ $10.4337 / 9781848445062.00027$

_- (2012). Easy to Say Hard to Do, Integrated Surface Water and Groundwater Management in the Murray-Darling Basin. Water Policy, 14(4): 709-24. doi.org/10.2166/wp.2012.129

Ross, A. \& Dovers, S. (2008). Very Hard Yards: Environmental policy integration in Australia. Australian Journal of Public Administration, 67(3): 245-60. doi.org/10.1111/j.1467-8500.2008.00585.x

Ross, A. \& Martinez-Santos, P. (2010). The Challenge of Groundwater Governance: Case studies from Australia and Spain. Regional Environmental Change, 10(3): 299-310. doi.org/10.1007/s10113009-0086-8

Sabatier, P., Focht, W., Lubell, M., Trachtenberg, Z., Vedlitz, A. \& Matlock, M. (2005). Swimming Upstream: Collaborative Approaches to Watershed Management. MIT Press, Cambridge, Massachusetts.

Svendsen, M. (2005). Irrigation and River Basin Management: Options for Governance and Institutions. CABI Publishing, Wallingford. doi.org/ $10.1079 / 9780851996721.0000$

Turral, H. \& Fullagar, I. (2007). Institutional Directions in Groundwater Management in Australia, In: Giordano, M. \& Villholth, K.G. (eds) The Agricultural Groundwater Revolution: Opportunities and Threats to Development. CAB International, Colombo, pp. 320-61. doi.org/ $10.1079 / 9781845931728.0320$

Vranesh, G. (1987). Colorado Water Law. Natural Resources Law Centre, Boulder.

Wilkinson, J. (1997). Water for Rural Production in NSW: Grand Designs and Changing Realities. NSW Parliamentary Library Research Service, Sydney.

Williams, R.M. (1998). The History of Community Involvement in Groundwater Policy Development - Lower Namoi Valley New South Wales. Proceedings of the AWWA 16th Federal Convention, Melbourne. 
MULTI-LEVEL GOVERNANCE

Wolfenden, J. \& Van der Lee, J. (2002). Social and Economic Assessment of Options/Recommendations for the Upper and Lower Namoi Groundwater and Sharing Plan. University of New England, Armidale.

Young, O. (2002). The Institutional Dimensions of Environmental Change: Fit, Interplay and Scale. MIT Press, Cambridge. 
This text is taken from Multi-level Governance: Conceptual challenges and case studies from Australia, edited by Katherine A. Daniell and Adrian Kay, published 2017 by ANU Press, The Australian National University, Canberra, Australia.

dx.doi.org/10.22459/MG.11.2017.15 